\title{
An Investigation on Self-Efficacy Perceptions of Prospective Teachers Related to Values Education
}

This study has been supported under the project 2017-8358 SBA-coded by Çukurova University Scientific Research Projects Coordination Unit. This article was presented at 5th International Congress on Social Sciences, China to Adriatic held in Tokyo, Japan, 18-23 September, 2017.

\author{
Alper Yontar ${ }^{1}$, Ali Altıkulaç² \\ ${ }^{1}$ Faculty of Education, Çukurova University, Adana, Turkey \\ ${ }^{2}$ Faculty of Education, Çukurova University, Adana, Turkey
}

\begin{abstract}
The aim of this research is to examine the opinions of the prospective teachers about the teaching of values and self-efficacy perceptions. As a working group, teacher candidates who are studying in their last at spring semester 2016-2017 academic year in Faculty of Education Classroom Training Department and Department of Social Studies Education, were included in the survey. In order to collect the data, a questionnaire prepared by the researchers was applied to the teacher candidates. In the questionnaire, there are open-ended questions about teacher candidates' views on values education and self-efficacy perceptions as well as personal information on gender and departmental variables. During the survey development process, it is provided to Submit questions prepared by researchers to expert opinions and make the necessary corrections according to the feedbacks. The draft survey form, in order to trial a sufficient number of teacher candidates have been tested for intelligibility. After this application, the questionnaire was prepared for the actual application. By analyzing the data obtained through the questionnaire by content analysis method, the categories and codes about teacher candidates' self-efficacy perceptions have reached the findings which have been analyzed according to sex and department variables have discussed with literature support.
\end{abstract}

Keywords: Candidate Teacher, Value Education, Self-efficacy Perception

\section{Introduction}

The rapid changes and developments in science and technology penetrate into societies' life styles, consuming habits and values. There are some positive effects of these rapid changes and developments such as; high quality of life, easy access to the knowledge and easier way of sharing it. However, the easier accessibility of sharing knowledge is a double-edged sword which might end up in the manipulation of information for negative intentions. At this point, values education and character and values education have an ever increasing importance on understanding the contemporary world.

The affective side of human beings include structures such as sentiments, preferences, choices, beliefs, affectivity, expectations, emotions of admiration, manners and attitudes, values, morals and ethics etc. (Bacanl1, 1999). We generally define the concept of values as "[t]he spiritually, ethically, communally or aesthetically recognized belief of superiority and importance of an action or an object or an entity" (Öncül, 2000). The humanity is born together with its values. The science and theory of values co-exist with the human beings and it constructs the core of human life for all the civilizations. The ethical notions such as 'true' or 'wrong', 'good' and 'bad', 'merits' and 'defects' have always been efficacious on the earthly activities of humans (Sharma, 2003).

According to John Dewey; the values means the things that should primarily be respected, appreciated and be known for its worth. It also means; an action of reaching and preserving something, besides, an action of reasoning on understanding the comparison of values' quantity and nature with other things (Venkataiah, 2007). The Notion of Values is stated as a thought of consensus; an aim, an essential ethical principle or beliefs that are accepted by the majority of communities or social groups who recognize them as the thing which provides the continuity of unity, its existence and operation for their well-being. The general characteristics of Values are its unifying facts that are indigenized by the community or individuals. They are the criterions that are believed to be for the good of society and the things that compensate the needs of the communities. They are not only the judgments that concern the conscience but also emotions and excitements. Values are instincts that are involved in individuals' consciousness and instincts that direct their behaviors (Özgüven, 1999).

Values are one of the most important basic elements that make individuals control themselves and societies control the individuals (Yazıc1, 2006). In the first phases of education where the major change in humans' notion of values and personalities are shaped, is of importance to provide a wellbalanced personality to the children for a brighter future. That's why: It is one of the most important missions of education system that is to bring certain Values to the individuals starting from their primary school age (Aladağ, 2012). The values that are brought to the students who are going to be the adults of future, need to be systematically evaluated (Dönmez, 2006). The main aim of values education is to inspire individuals to recognize the practical methods of deepening and choosing their personal, social, ethical and spiritual values (Balc1, 2008).

Teachers help their students to think profoundly whether they reflect their beliefs on their behaviours; teachers give opportunities for their students to construct their own values

\section{Volume 6 Issue 12, December 2017}




\section{International Journal of Science and Research (IJSR) \\ ISSN (Online): 2319-7064}

Index Copernicus Value (2016): 79.57 | Impact Factor (2015): 6.391

through letting them do their own preferences and see the consequences of their preferences either in or outside the class (Simon, Hove \& Kirschenbaum, 1972). On one hand, the contemporary teachers work hard to discover the potential of students in their success in the classes and on the other hand, the teachers try to manage in-class exercises for the character education which has an ever-increasing importance (Schwartz, 2008). A teacher as an educator of values has to find or create opportunities for children to complete their ethical development through the methods of inductive reasoning (Suvirananda, 2005). A teacher must show what is going good or bad to the students; it is one of their responsibilities to give examples to the situations, pointing out whether s/he approves of the actions that take place in the class and s/he must make an explanation through reasoning (Halstead and Taylor, 2000). A teacher must show love and respect; s/he must be fair, s/he must try to correct the negative attitudes with appropriate ways and s/he must avoid attitudes such as mocking, favouring which would harm students' self-confidence and respect. Teachers ought to approve of the proper behaviours of the students and they should comfort them in case they make mistakes. Teachers should organize an appropriate space for the students to show their ideas and interests freely and teachers should let know their students that their perspectives are respected (Üstünyer, 2009).

If the required necessity is not given to the values education, the negative effects would cause cultural and ethical corruption and eventually, values erosion in the society. Values education is a process that starts in the family, continues in school and later with the individual's environment throughout his/her life. At this point, the second most important operator after the family, the teachers, and their notion of sufficiency in this process is of importance. Hence, it is necessary to reveal; to what extent the teacher candidates who are responsible for giving values education, see themselves sufficient for such a mission.

\section{Method}

In this research the survey model was used. The survey researches are studies that aim to collect data to determine a certain feature of a specific group. In this research, the consistent and varied data sets are collected accordingly to the multiple methods study and to make analysis of these data sets, qualitative and quantitative data analysis methods have been used together. Balc1, (2013) describes multiple methods study as an application of consistent and varied data collections [that are also consistent with the same paradigm] within a single research paradigm. The study group of this research is determined as a group consists of 110 people in total, of teacher candidates who study Social Studies Teaching and Classroom Teaching (78 Classroom Teaching, 32 Social Studies Teaching). The collected quantitative data is subjected to descriptive statistics and qualitative data is subjected to content analysis; the obtained results are evaluated with their correspondences to each other. The researchers have created The Survey of Teacher Candidates' Sense of Self-Efficacy on Values Education to collect data. The scale consists of quantitative and qualitative questions which aim to depict the participants' notion about the subject. The main problem sentence of this research is as below:

What are the notions of sense of self-efficacy and opinions of teacher candidates- who study Social Studies Teaching and Classroom Teaching- about values education?

This research aims to seek answers on teacher candidates' opinions and sense of self-efficacy on values education by taking their gender and field variables into consideration. The questions of this research are listed as below:

1) Teacher candidates' opinions on the education of values education in schools;

a) What kind of dispersion is there on the variable of gender?

b) What kind of dispersion is there considering the field they study?

2) Teacher candidates' reasons on supporting the education of values education in schools;

a) What kind of dispersion is there on the variable of gender?

b) What kind of dispersion is there considering the field they study?

3) Teacher candidates' opinions on the sufficiency of values education given in schools;

a) What kind of dispersion is there on the variable of gender?

b) What kind of dispersion is there considering the field they study?

4) Teacher candidates' reasons on their perspective about sufficiency of values education given in schools;

a) What kind of dispersion is there on the variable of gender?

b) What kind of dispersion is there considering the field they study?

5) Teacher candidates' opinions on sufficiency of values education that they receive in their undergraduate programme;

a) What kind of dispersion is there on the variable of gender?

b) What kind of dispersion is there considering the field they study?

6) Teacher candidates' reasons on their perspective about sufficiency of values education that they receive in their undergraduate programme;

a) What kind of dispersion is there on the variable of gender?

b) What kind of dispersion is there considering the field they study?

7) Teacher candidates' suggestions for the values education that they receive in their undergraduate programme;

a) What kind of dispersion is there on the variable of gender?

b) What kind of dispersion is there considering the field they study?

The age of information and technology brought cognitive fields into prioritized positions which forced affective fields to have insufficient space, however, affective fields' everincreasing importance points out a necessity.

Through this study, teacher candidates' -who are going to be the most important operators of teaching values education, 


\section{International Journal of Science and Research (IJSR) \\ ISSN (Online): 2319-7064}

Index Copernicus Value (2016): 79.57 | Impact Factor (2015): 6.391

given in schools- notion of the values education given in their undergraduate programme will be explored.

This study points out a fact to improve teacher candidates' compatibility to their jobs in which they are expected to teach values education in schools and this study also stresses out the importance of the values education that the teacher candidates receive.

In this study, the survey model is used in order to put the teacher candidates' opinions on values education and their self-efficacy.

To this research, 110 teacher candidates on their senior year from the fields of Social Studies Teaching and Classroom Teaching participated, from a public university in the academic year of 2016-2017.

The detailed information about the study group is given in the charts below:

Chart 1: The Frequencies and Percentage Dispersion of the Study Group, Considering the Participants' Gender Variables

\begin{tabular}{|c|c|c|}
\hline Gender & $\mathrm{N}$ & $\%$ \\
\hline Female & 65 & 59 \\
\hline Male & 45 & 41 \\
\hline Total & 110 & 100 \\
\hline
\end{tabular}

As it can be seen in Chart 1, more than half of the study group consists of female students. It is because the fields of Social Studies Teaching and Classroom Teaching bachelors programme are predominantly preferred by the female students.

Chart 2: The Frequencies and Percentage Dispersion of Study Group, Considering the Field Variable

\begin{tabular}{|l|c|c|}
\hline \multicolumn{1}{|c|}{ Field (Department) } & N & $\%$ \\
\hline Classroom Teaching & 78 & 71 \\
\hline Social Studies Teaching & 32 & 29 \\
\hline Total & 110 & 100 \\
\hline
\end{tabular}

It can be inferred that the majority of participants are from department of Classroom Teaching. The reason of this result is that the department of Classroom Teaching has three branches whereas Social Studies Teaching has only one branch in their undergraduate programme in the university where this study takes place.

\section{The Data Collection Device}

The data is collected through the questionnaire that is developed by the researchers known as "The Survey of Teacher Candidates' Sense of Self-Efficacy on Values Education".

The development process of questionnaire;

- Taking professional help from the experts for the questions that are prepared,

- Evaluating the feedbacks and re-arranging the questionnaire,

- Providing and performing the questionnaire on the required number of teacher candidates,
- The process of making questionnaire ready for application. The final format is determined.

- In the questionnaire, there are questions aimed at teacher candidates' gender and field variables. Besides, there are open-ended questions directed at understanding the teacher candidates' opinions on values education, sense of selfefficacy on values education and what reasons they offer to support their points.

- In the data collection of the research: The researchers did the necessary explanations to the teacher candidates and gave them the questionnaires.

- The collected quantitative data is subjected to descriptive statistics and qualitative data is subjected to content analysis.

\section{Findings}

The data on the quantitative findings of the research are given in the charts below.

Chart 3. Gives the information of teacher candidates' opinion on whether values education should be given in schools, considering the participants' gender variables.

Chart 3: The dispersion of teacher candidates' opinion on whether values education should be given in schools, considering the participants' gender variables

\begin{tabular}{|c|c|c|c|c|c|c|}
\hline \multirow{2}{*}{$\begin{array}{c}\text { Values Education } \\
\text { in Schools }\end{array}$} & \multicolumn{2}{|c|}{ Female } & \multicolumn{2}{|c|}{ Male } & \multicolumn{2}{|c|}{ Total } \\
\cline { 2 - 7 } & $\mathrm{f}$ & $\boldsymbol{\%}$ & $\mathrm{f}$ & $\mathbf{\%}$ & $\mathrm{f}$ & $\boldsymbol{\%}$ \\
\hline It should be given & 65 & 100 & 44 & 98 & 109 & 99 \\
\hline It shouldn't be given & 0 & 0 & 1 & 2 & 1 & 1 \\
\hline Total & 65 & 100 & 45 & 100 & 110 & 100 \\
\hline
\end{tabular}

As it can be inferred from the Chart 3, except one male participant, all the participants agree on that: Values education should be given in schools.

Chart 4. Provides information on teacher candidates' opinion on whether values education should be given in schools, considering the participants' field of study variables:

Chart 4: The dispersion of teacher candidates' opinion on whether values education should be given in schools, considering the participants' field of study variables.

\begin{tabular}{|c|c|c|c|c|c|c|}
\hline \multirow{2}{*}{$\begin{array}{c}\text { Values Education in } \\
\text { Schools }\end{array}$} & \multicolumn{2}{|c|}{$\begin{array}{c}\text { Classroom } \\
\text { Tch. }\end{array}$} & \multicolumn{2}{|c|}{ Social Studies } & \multicolumn{2}{|c|}{ Total } \\
\cline { 2 - 8 } & $\mathrm{f}$ & $\%$ & $\mathrm{f}$ & $\%$ & $\mathrm{f}$ & $\%$ \\
\hline It should be given & 77 & 99 & 32 & 100 & 109 & 99 \\
\hline It shouldn't be given & 1 & 1 & 0 & 0 & 1 & 1 \\
\hline Total & 78 & 100 & 32 & 100 & 110 & 100 \\
\hline
\end{tabular}

It can be seen that except one student from Classroom Teaching, all agree on the point that values education should be given in schools.

Teacher candidates' opinion on sufficiency of values education given in schools, considering the participants' gender variables, is given in Chart 5: 


\section{International Journal of Science and Research (IJSR) \\ ISSN (Online): 2319-7064}

Index Copernicus Value (2016): 79.57 | Impact Factor (2015): 6.391

Chart 5: The dispersion of teacher candidates' opinion on sufficiency of values education given in schools, considering the participants' gender variables

\begin{tabular}{|c|c|c|c|c|c|c|}
\hline Sufficiency of Values & \multicolumn{2}{|c|}{ Female } & \multicolumn{2}{c|}{ Male } & \multicolumn{2}{c|}{ Total } \\
\cline { 2 - 7 } Education in Schools & $\mathrm{f}$ & $\%$ & $\mathrm{f}$ & $\%$ & $\mathrm{f}$ & $\%$ \\
\hline Sufficient & 10 & 15 & 8 & 18 & 18 & 16 \\
\hline Insufficient & 55 & 85 & 37 & 82 & 92 & 84 \\
\hline Total & 65 & 100 & 45 & 100 & 110 & 100 \\
\hline
\end{tabular}

Chart 5, shows that the majority of the participants (\%84) find the values education given in schools insufficient. Considering the gender variables, it can be inferred that both male and female participants have a consensus on the point that the values education given in schools is inadequate.

Teacher candidates' opinion on sufficiency of values education given in schools, considering the participants' field of study variables, is given in Chart 6 :

Chart 6: The dispersion of teacher candidates' opinion on sufficiency of values education given in schools, considering the participants' field of study variables

\begin{tabular}{|c|c|c|c|c|c|c|}
\hline $\begin{array}{c}\text { Sufficiency of } \\
\text { Values Education } \\
\text { in Schools }\end{array}$ & $\begin{array}{c}\text { Classroom } \\
\text { Teaching }\end{array}$ & \multicolumn{2}{|c|}{$\begin{array}{c}\text { Social } \\
\text { Studies } \\
\text { Teaching. }\end{array}$} & \multicolumn{2}{|c|}{ Total } \\
\cline { 2 - 7 } & $\mathrm{f}$ & $\%$ & $\mathrm{f}$ & $\%$ & $\mathrm{f}$ & $\%$ \\
\hline Sufficient & 13 & 17 & 5 & 16 & 18 & 16 \\
\hline Insufficient & 65 & 83 & 27 & 84 & 92 & 84 \\
\hline Total & 78 & 100 & 32 & 100 & 110 & 100 \\
\hline
\end{tabular}

It can be inferred from Chart 6 that the participants from both fields of studies have a close ratio on their perspective about sufficiency of values education in schools.

Teacher candidates' opinion on sufficiency of values education that they receive in their undergraduate programme, considering the participants' gender variables is given in Chart 7:

Chart 7: The dispersion of teacher candidates' opinion on sufficiency of values education that they receive in their undergraduate programme, considering the participants' gender variables

\begin{tabular}{|c|c|c|c|c|c|c|}
\hline $\begin{array}{c}\text { Sufficiency of Values } \\
\text { Education in }\end{array}$ & \multicolumn{2}{|c|}{ Female } & \multicolumn{2}{|c|}{ Male } & \multicolumn{2}{c|}{ Total } \\
\cline { 2 - 7 } Undergraduate Programme & $\mathrm{f}$ & $\%$ & $\mathrm{f}$ & $\%$ & $\mathrm{~F}$ & $\%$ \\
\hline Sufficient & 20 & 31 & 11 & 24 & 31 & 28 \\
\hline Insufficient & 45 & 69 & 34 & 76 & 79 & 72 \\
\hline Total & 65 & 100 & 45 & 100 & 110 & 100 \\
\hline
\end{tabular}

Considering what Chart 7 suggests, it can be inferred that the male students find values education given in the undergraduate programme insufficient more than the female students.

The participants' opinion on sufficiency of values education that they receive in their undergraduate programme, considering the participants' field of study variables, is given in Chart 8:
Chart 8: The dispersion of the participants' opinion on sufficiency of values education that they receive in their undergraduate programme, considering the participants' field of study variables

\begin{tabular}{|c|c|c|c|c|c|c|}
\hline $\begin{array}{c}\text { Sufficiency of Values } \\
\text { Education in } \\
\begin{array}{c}\text { Undergraduate } \\
\text { Programme }\end{array}\end{array}$ & \multicolumn{2}{|c|}{$\begin{array}{c}\text { Classroom } \\
\text { Teaching }\end{array}$} & $\begin{array}{c}\text { Social Studies } \\
\text { Teaching }\end{array}$ & \multicolumn{2}{|c|}{ Total } \\
\cline { 2 - 7 } & $\mathrm{f}$ & $\%$ & $\mathrm{f}$ & $\%$ & $\mathrm{~F}$ & $\%$ \\
\hline Sufficient & 19 & 24 & 12 & 37,5 & 31 & 28 \\
\hline Insufficient & 59 & 76 & 20 & 62,5 & 79 & 72 \\
\hline Total & 78 & 100 & 32 & 100 & 110 & 100 \\
\hline
\end{tabular}

It can be seen in the Chart 8 that Classroom Teaching students find the values education in the undergraduate programme insufficient which they study more than the Social Studies Teaching students in their undergraduate programme. The reason behind this data might be the elective course, "Values Education" that Social Studies Teaching students receive during their undergraduate programme.

Chart 9 points out the reasons that teacher candidates explain why they support values education to be given in schools:

Chart 9: The dispersion of teacher candidates' explanation of their reasons of supporting values education to be given in schools, considering the participants' gender variables

\begin{tabular}{|c|c|c|c|}
\hline $\begin{array}{c}\text { The Reasons, Why Teacher } \\
\text { Candidates Support Values } \\
\text { Educations to be Given in Schools }\end{array}$ & $\begin{array}{c}\text { Female } \\
(\mathrm{N}=65)\end{array}$ & $\begin{array}{c}\text { Male } \\
(\mathrm{N}=45)\end{array}$ & $\begin{array}{c}\text { Total } \\
(\mathrm{N}=110)\end{array}$ \\
\hline $\begin{array}{c}\text { Consciousness-raising and informing } \\
\text { of the students }\end{array}$ & 22 & 8 & 30 \\
\hline $\begin{array}{c}\text { Its efficiency on children's } \\
\text { development/character development }\end{array}$ & 14 & 7 & 21 \\
\hline Its support to conserve social order & 10 & 11 & 21 \\
\hline Its enabling of cultural transmission & 6 & 9 & 15 \\
\hline The need to values/moral emotions & 8 & 5 & 13 \\
\hline Its importance on life/behaviours & 5 & 6 & 11 \\
\hline $\begin{array}{c}\text { The values learnt from family and } \\
\text { surroundings are limited }\end{array}$ & 3 & 6 & 9 \\
\hline $\begin{array}{c}\text { It is efficient on communal } \\
\text { progression }\end{array}$ & 2 & 3 & 5 \\
\hline $\begin{array}{c}\text { It is of top priority } \\
\text { People must create their own values } \\
\text { education. }\end{array}$ & 0 & 1 & 1 \\
\hline
\end{tabular}

When the chart 9 is examined, it can be suggested that female participants of the study group, mostly reasons their support of values education through its function of "consciousness-raising and informing of the students"; whereas the male participants of the study group, mostly reasons their support of values education in schools through its function of "supporting to conserve social order".

Chart 10. Presents the teacher candidates' reasons on supporting the values education to be given in school, considering the participants' field of study: 


\section{International Journal of Science and Research (IJSR) \\ ISSN (Online): 2319-7064}

Index Copernicus Value (2016): 79.57 | Impact Factor (2015): 6.391

Chart 10: The dispersion of the teacher candidates' reasons on supporting the values education to be given in school, considering the participants' field of study variables

\begin{tabular}{|c|c|c|c|}
\hline $\begin{array}{c}\text { The Reasons, Why Teacher } \\
\text { Candidates Support Values } \\
\text { Educations to be Given in } \\
\text { Schools }\end{array}$ & $\begin{array}{c}\text { Classroom } \\
\text { Teaching } \\
(\mathrm{N}=78)\end{array}$ & $\begin{array}{c}\text { Social Studies } \\
\text { Teaching } \\
(\mathrm{N}=32)\end{array}$ & $\begin{array}{c}\text { Total } \\
(\mathrm{N}=110)\end{array}$ \\
\hline $\begin{array}{l}\text { Consciousness-raising and } \\
\text { informing of the students }\end{array}$ & 26 & 4 & 30 \\
\hline $\begin{array}{c}\text { Its efficiency on children's } \\
\text { development/character } \\
\text { development }\end{array}$ & 12 & 9 & 21 \\
\hline $\begin{array}{c}\text { Its support to conserve social } \\
\text { order }\end{array}$ & 16 & 5 & 21 \\
\hline $\begin{array}{l}\text { Its enabling of cultural } \\
\text { transmission }\end{array}$ & 9 & 6 & 15 \\
\hline $\begin{array}{c}\text { The need to values/moral } \\
\text { emotions }\end{array}$ & 7 & 6 & 13 \\
\hline $\begin{array}{l}\text { Its importance on } \\
\text { life/behaviours }\end{array}$ & 6 & 5 & 11 \\
\hline $\begin{array}{l}\text { The values learnt from family } \\
\text { and surroundings are limited }\end{array}$ & 5 & 4 & 9 \\
\hline $\begin{array}{c}\text { It is efficient on communal } \\
\text { progression }\end{array}$ & 5 & 0 & 5 \\
\hline It is of top priority & 2 & 2 & 4 \\
\hline $\begin{array}{c}\text { People must create their own } \\
\text { values education. }\end{array}$ & 1 & 0 & 1 \\
\hline
\end{tabular}

It can be inferred that Classroom Teaching teacher candidates mostly choose the reason "Consciousness-raising and informing of the students" whereas Social Studies Teaching students mostly choose "Its efficiency on children's development/character development". Moreover, Chart 10 provides an alternative answer from a student who supports that values education should not be given in schools because s/he claims "people must create their own values education".

Teacher candidates' reasons on their perspective of sufficiency of values education given in the schools, considering the participants' gender variable, are given in the Chart 11:

Chart 11: The dispersion of teacher candidates' reasons on their perspective of sufficiency of values education given in the schools, considering the participants' gender variables

\begin{tabular}{|c|c|c|c|}
\hline $\begin{array}{c}\text { Reasons on Participants' perspective of } \\
\text { Sufficiency of Values Education Given } \\
\text { in Schools }\end{array}$ & $\begin{array}{c}\text { Female } \\
(\mathrm{N}=65)\end{array}$ & $\begin{array}{c}\text { Male } \\
(\mathrm{N}=45)\end{array}$ & $\begin{array}{c}\text { Total } \\
(\mathrm{N}=110)\end{array}$ \\
\hline Teachers do not put much effort & 25 & 10 & 35 \\
\hline $\begin{array}{c}\text { Teachers are insensible } \\
\begin{array}{c}\text { Academic achievement criterion does } \\
\text { not contain values }\end{array}\end{array}$ & 14 & 6 & 20 \\
\hline The given education is superficial & 4 & 9 & 13 \\
\hline $\begin{array}{c}\text { The values in the programme, are } \\
\text { transferred in connection with } \\
\text { information }\end{array}$ & 5 & 2 & 7 \\
\hline $\begin{array}{c}\text { Teachers are ill-equipped and ill- } \\
\text { informed }\end{array}$ & 4 & 2 & 6 \\
\hline $\begin{array}{c}\text { Teachers are giving the necessary } \\
\text { education }\end{array}$ & 2 & 1 & 3 \\
\hline $\begin{array}{c}\text { Consciousness-raising is } \\
\text { insufficient/non-existent and only a } \\
\text { theoretical information is provided }\end{array}$ & 3 & 0 & 3 \\
\hline Values education given in schools is & 2 & 1 & 3 \\
\hline
\end{tabular}

\begin{tabular}{|c|c|c|c|}
\hline insufficient & & & \\
\hline Teachers fail to be role-models & 2 & 1 & 3 \\
\hline Children exhibit unwanted behaviours & 1 & 2 & 3 \\
\hline Teachers are closed to novelty & 1 & 1 & 2 \\
\hline $\begin{array}{c}\text { The relation between parents-teachers- } \\
\text { students go under an alteration }\end{array}$ & 1 & 1 & 2 \\
\hline $\begin{array}{c}\text { Appropriate methods/technics are not } \\
\text { used }\end{array}$ & 1 & 1 & 2 \\
\hline $\begin{array}{c}\text { Only the basic information should be } \\
\text { provided and students should learn the } \\
\text { rest by experiencing. }\end{array}$ & 0 & 1 & 1 \\
\hline
\end{tabular}

Chart 11 suggests that both female and male participants reason the insufficiency of values education given in school by claiming that "teachers do not put much effort". Those who support the suggestion that the given education in schools is sufficient, reason their point by saying "The values in the programme, are transferred in connection with information".

Chart 12 explains teacher candidates' reasons on their perspective of sufficiency of values education given in the schools, considering the participants' field of study variables:

Chart 12: The dispersion of teacher candidates' reasons on their perspective of sufficiency of values education given in the schools, considering the participants' field of study variables

\begin{tabular}{|c|c|c|c|}
\hline $\begin{array}{c}\text { Reasons on Participants' } \\
\text { perspective of Sufficiency of } \\
\text { Values Education Given in } \\
\text { Schools } \\
\end{array}$ & $\begin{array}{c}\text { Classroom } \\
\text { Teaching } \\
(\mathrm{N}=78)\end{array}$ & \begin{tabular}{|l} 
Social \\
Studies \\
Teaching \\
$(\mathrm{N}=32)$ \\
\end{tabular} & $\begin{array}{c}\text { Total } \\
(\mathrm{N}=110)\end{array}$ \\
\hline Teachers do not put much effort & 30 & 5 & 35 \\
\hline Teachers are insensible & 20 & 0 & 20 \\
\hline $\begin{array}{c}\text { Academic achievement criterion } \\
\text { does not contain values }\end{array}$ & 13 & 4 & 17 \\
\hline $\begin{array}{l}\text { The given education is } \\
\text { superficial }\end{array}$ & 1 & 12 & 13 \\
\hline $\begin{array}{c}\text { The values in the programme, } \\
\text { are transferred in connection } \\
\text { with information }\end{array}$ & 7 & 0 & 7 \\
\hline $\begin{array}{c}\text { Teachers are ill-equipped and ill- } \\
\text { informed }\end{array}$ & 6 & 0 & 6 \\
\hline $\begin{array}{l}\text { Teachers are giving the } \\
\text { necessary education }\end{array}$ & 2 & 1 & 3 \\
\hline $\begin{array}{l}\text { Consciousness-raising is } \\
\text { insufficient/non-existent and } \\
\text { only a theoretical information is } \\
\text { provided }\end{array}$ & 3 & 0 & 3 \\
\hline $\begin{array}{l}\text { Values education given in } \\
\text { schools is insufficient }\end{array}$ & 2 & 1 & 3 \\
\hline Teachers fail to be role-models & 1 & 2 & 3 \\
\hline $\begin{array}{c}\text { Children exhibit unwanted } \\
\text { behaviours }\end{array}$ & 1 & 2 & 3 \\
\hline Teachers are closed to novelty & 2 & 0 & 2 \\
\hline $\begin{array}{l}\text { The relation between parents- } \\
\text { teachers-students go under an } \\
\text { alteration }\end{array}$ & 2 & 0 & 2 \\
\hline $\begin{array}{l}\text { Appropriate methods/technics } \\
\text { are not used }\end{array}$ & 0 & 2 & 2 \\
\hline $\begin{array}{c}\text { Only the basic information } \\
\text { should be provided and students } \\
\text { should learn the rest by } \\
\text { experiencing. }\end{array}$ & 1 & 0 & 1 \\
\hline
\end{tabular}




\section{International Journal of Science and Research (IJSR) \\ ISSN (Online): 2319-7064}

Index Copernicus Value (2016): 79.57 | Impact Factor (2015): 6.391

The students of Classroom Teaching find the given education insufficient by suggesting the reason "Teachers do not put much effort" whereas the participants from Social Studies Teaching mostly give the reason "The given education is superficial". Another point that can be inferred from the chart 12 is that, people who find the given education sufficient reason their point by claiming that "The values in the programme are transferred in connection with information" and this point is only acknowledged by the Classroom Teaching students.

Teacher candidates' reasons on the sufficiency of values education that they receive during their undergraduate programme, considering the participants' gender variables are given in the Chart 13:

Chart 13: The dispersion of Teacher candidates' reasons on the sufficiency of values education that they receive during their undergraduate programme, considering the participants' gender variables

\begin{tabular}{|c|c|c|c|}
\hline $\begin{array}{c}\text { Teacher Candidates' Reasons on the } \\
\text { Sufficiency of Values Education that } \\
\text { They Receive in Their Undergraduate } \\
\text { Programme }\end{array}$ & $\begin{array}{c}\text { Female } \\
(\mathrm{N}=65)\end{array}$ & $\begin{array}{c}\text { Male } \\
(\mathrm{N}=45)\end{array}$ & $\begin{array}{c}\text { Total } \\
(\mathrm{N}=110)\end{array}$ \\
\hline It is being slurred over & 20 & 17 & 37 \\
\hline They only transfer information & 14 & 11 & 25 \\
\hline $\begin{array}{c}\text { The necessary explanation/informing is } \\
\text { given }\end{array}$ & 16 & 9 & 25 \\
\hline $\begin{array}{c}\text { The facilities are insufficient } \\
\begin{array}{c}\text { It is insufficient because it is elective } \\
\text { (There are people who cannot take the } \\
\text { course) }\end{array}\end{array}$ & 13 & 10 & 23 \\
\hline $\begin{array}{c}\text { We are given the opportunity to evaluate } \\
\text { what we are taught }\end{array}$ & 1 & 1 & 2 \\
\hline $\begin{array}{c}\text { University's organizational structure } \\
\text { helps learning }\end{array}$ & 1 & 0 & 1 \\
\hline We do sufficient works and home-works & 1 & 0 & 1 \\
\hline Instructor manages to be role-model & 1 & 0 & 1 \\
\hline $\begin{array}{c}\text { I cannot spare time because } \\
\text { KPSS/Exams worry me }\end{array}$ & 0 & 1 & 1 \\
\hline
\end{tabular}

The data on Chart 13, shows that both female and male participants reason the insufficiency of the values education that they receive in their undergraduate programme, mostly by claiming that "It is being slurred over". The students, who find the education they receive sufficient, support their point mostly by claiming that "The necessary explanation/ informing are given".

The data that show the teacher candidates' reasons on the sufficiency of values education that they receive during their undergraduate programme, considering the participants' field of study variables are given in the Chart 14:

Chart 14: The dispersion of the teacher candidates' reasons on the sufficiency of values education that they receive during their undergraduate programme, considering the participants' field of study variables

\begin{tabular}{|c|c|c|c|}
$\begin{array}{c}\text { Teacher Candidates' Reasons on } \\
\text { the Sufficiency of Values } \\
\text { Education that They Receive in } \\
\text { Their Undergraduate Programme }\end{array}$ & $\begin{array}{c}\text { Classroom } \\
\text { Teaching } \\
(\mathrm{N}=78)\end{array}$ & $\begin{array}{c}\text { Social } \\
\text { Studies } \\
\text { Teaching } \\
(\mathrm{N}=32)\end{array}$ & $\begin{array}{c}\text { Total } \\
(\mathrm{N}=110)\end{array}$ \\
\hline It is being slurred over & 31 & 6 & 37 \\
\hline They only transfer information & 20 & 5 & 25 \\
\hline
\end{tabular}

\begin{tabular}{|c|c|c|c|}
\hline $\begin{array}{c}\text { The necessary } \\
\text { explanation/informing is given }\end{array}$ & 15 & 10 & 25 \\
\hline $\begin{array}{c}\text { The facilities are insufficient } \\
\text { It is insufficient because it is } \\
\text { elective (There are people who } \\
\text { cannot take the course) }\end{array}$ & 17 & 6 & 23 \\
\hline $\begin{array}{c}\text { We are given the opportunity to } \\
\text { evaluate what we are taught }\end{array}$ & 1 & 1 & 2 \\
\hline $\begin{array}{c}\text { University's organizational } \\
\text { structure helps learning }\end{array}$ & 1 & 0 & 1 \\
\hline $\begin{array}{c}\text { We do sufficient works and } \\
\text { home-works }\end{array}$ & 1 & 0 & 1 \\
\hline $\begin{array}{c}\text { Instructor manages to be role- } \\
\text { model }\end{array}$ & 1 & 0 & 1 \\
\hline $\begin{array}{c}\text { I cannot spare time because } \\
\text { KPSS/Exams worry me }\end{array}$ & 0 & 1 & 1 \\
\hline
\end{tabular}

The most common point in the Chart 14 is that the students from the both fields agree on the insufficiency of the given education and they suggest that "It is being slurred over". An interesting another data on the chart is that students from the Social Studies Teaching who find the given education sufficient frequently suggested that "The necessary explanation/informing is given".

Teacher candidates' suggestions for the values education that they receive in their undergraduate programme, considering the participants' gender variables are given in the Chart 15:

Chart 15: The dispersion of teacher candidates' suggestions for the values education that they receive in their undergraduate programme, considering the participants' gender variables

\begin{tabular}{|c|c|c|c|}
\hline $\begin{array}{c}\text { Suggestions for Values Education in } \\
\text { the Undergraduate Programme }\end{array}$ & $\begin{array}{c}\text { Female } \\
(\mathrm{N}=65)\end{array}$ & $\begin{array}{c}\text { Male } \\
(\mathrm{N}=45)\end{array}$ & $\begin{array}{c}\text { Total } \\
(\mathrm{N}=110)\end{array}$ \\
\hline $\begin{array}{c}\text { There should be concentration on the } \\
\text { application (How it should be done) }\end{array}$ & 32 & 16 & 48 \\
\hline $\begin{array}{c}\text { It should be taken as a different } \\
\text { subject/course and developed }\end{array}$ & 13 & 10 & 23 \\
\hline $\begin{array}{c}\text { Theoretical information should be } \\
\text { given, applications should be } \\
\text { performed }\end{array}$ & 5 & 5 & 10 \\
\hline $\begin{array}{c}\text { Instructor should manage to be a role- } \\
\text { model }\end{array}$ & 4 & 0 & 4 \\
\hline $\begin{array}{c}\text { Actual/example study materials } \\
\text { should be given }\end{array}$ & 1 & 3 & 4 \\
\hline It should be given along with drama & 3 & 1 & 4 \\
\hline $\begin{array}{c}\text { It should be associated with all the } \\
\text { classes and it should be made a } \\
\text { lifestyle }\end{array}$ & 2 & 1 & 3 \\
\hline $\begin{array}{c}\text { It should have the quality of making } \\
\text { individual self-recognized and } \\
\text { coherent with the community }\end{array}$ & 2 & 1 & 3 \\
\hline It should be made interesting & 2 & 1 & 3 \\
\hline $\begin{array}{c}\text { Methods and techniques should be } \\
\text { taught }\end{array}$ & 2 & 0 & 2 \\
\hline
\end{tabular}

Both female and male participants agree mostly on the point that "there should be concentration on the application (how it should be done)" as it is understood from the Chart 15. It is also interesting that the participants frequently suggest that values education "should be taken as a different subject/ course and developed".

\section{Volume 6 Issue 12, December 2017}




\section{International Journal of Science and Research (IJSR) \\ ISSN (Online): 2319-7064}

Index Copernicus Value (2016): 79.57 | Impact Factor (2015): 6.391

Teacher candidates' suggestions for the values education that they receive in their undergraduate programme, considering the participants' field of study variable are given in the Chart 16:

Chart 16: The dispersion of teacher candidates' suggestions for the values education that they receive in their undergraduate programme, considering the participants' field of study variables

\begin{tabular}{|c|c|c|c|}
\hline $\begin{array}{c}\text { Suggestions for Values Education } \\
\text { in the Undergraduate Programme }\end{array}$ & $\begin{array}{c}\text { Classroom } \\
\text { Teaching } \\
\text { (N=78) }\end{array}$ & $\begin{array}{c}\text { Social } \\
\text { Studies } \\
\text { Teaching } \\
(\mathrm{N}=32)\end{array}$ & $\begin{array}{c}\text { Total } \\
(\mathrm{N}=110)\end{array}$ \\
\hline $\begin{array}{c}\text { There should be concentration on } \\
\text { the application (How it should be } \\
\text { done) }\end{array}$ & 36 & 12 & 48 \\
\hline $\begin{array}{c}\text { It should be taken as a different } \\
\text { subject/course and developed }\end{array}$ & 19 & 4 & 23 \\
\hline $\begin{array}{c}\text { Theoretical information should be } \\
\text { given, applications should be } \\
\text { performed }\end{array}$ & 7 & 3 & 10 \\
\hline $\begin{array}{c}\text { Instructor should manage to be a } \\
\text { role-model }\end{array}$ & 4 & 0 & 4 \\
\hline $\begin{array}{c}\text { Actual/example study materials } \\
\text { should be given }\end{array}$ & 0 & 4 & 4 \\
\hline $\begin{array}{c}\text { It should be given along with } \\
\text { drama }\end{array}$ & 4 & 0 & 4 \\
\hline $\begin{array}{c}\text { It should be associated with all the } \\
\text { classes and it should be made a } \\
\text { lifestyle }\end{array}$ & 3 & 0 & 3 \\
\hline $\begin{array}{c}\text { It should have the quality of } \\
\text { making individual self-recognized } \\
\text { and coherent with the community }\end{array}$ & 2 & 1 & 3 \\
\hline It should be made interesting & 2 & 1 & 3 \\
\hline $\begin{array}{c}\text { Methods and techniques should be } \\
\text { taught }\end{array}$ & 1 & 1 & 2 \\
\hline
\end{tabular}

When the Chart 16 evaluated, it can be inferred that the students from both fields (departments) agree on the suggestion that is "There should be concentration on the application (How it should be done)". In pursuit of this suggestion, the second most voted one is "It should be taken as a different subject/course and developed".

Here are some examples from teacher candidates' own statements:

4. $\quad 14 \mathrm{M}($ Male): "We've dealt with this inside a syllabus of a Social Studies Teaching. Instead of this, it sounds rather rewarding if it was given as a separate course."

5. $18 \mathrm{~F}($ Female): "There should be an elective or required course about values education and abstract concepts."

6. $26 \mathrm{~F}$ (Female): "It should be given as a separate course in the undergraduate programme. Observation and application should be provided. That is to say, the education must be experiential."

7. $38 \mathrm{~F}$ (Female): "Instead of giving us elective courses that are no use, they could give us values education"

8. 52F(Female): "We could practice the methods and techniques of values education on a school under application of this procedure-maybe with a troubled student- and observe the changes examined."

\section{Conclusion}

In this research where teacher candidates' opinion on values education and sense of self-efficacy examined, the following results have been achieved:

- All the teacher candidates except one, state that values education should be given in schools. The most common reason to support their point has been "consciousnessraising and informing of the students"

- Most of the participants (about \%84) agree on the point that values education given in the schools is insufficient. The most common reason to support this point has been "teachers' not putting much effort". There is a similar outcome as it has been in the study of Altunay and Yalçınkaya (2011), teacher candidates place great importance to the values education.

- The majority of teacher candidates (about \%72) claim that the values education that they receive in their undergraduate programme is insufficient. They support their point mostly by stating that "It is being slurred over". Similar outcome has been observed in the study of Şahin (2013) in which a significant amount of social studies teacher candidates (about \%84) found the education they receive, insufficient.

- The most common (about \%44) suggestion about the values education that candidates receive in their undergraduate programme has been that "there should be concentration on the application [of what is taught]" In a different study, a part of teacher candidates (about \%31) also stressed out the importance of the application of what is taught in the values education.

- When the remarks about values education's sufficiency and its being given in schools are examined; considering the participants' gender and field of study variables, it can be inferred that there is a close ratio in the consensus.

- The data about the gender variables shows that the male candidates find values education more insufficient compared to the female candidates.

- The data about the field of study variables show that Classroom Teaching participants find values education that they receive more insufficient, compared to the Social Studies Teaching participants.

- The most important result for us is that the teacher candidates find values education insufficient and they point out the necessity of having a new programme/course for the values education in which there should be concentration on the application.

Based on the result of the research, the following suggestions have been developed:

- The majority of teacher candidates think that the values education that they receive is insufficient. Hence, a required course about values education can be added to the undergraduate programme. Cihan (2014) points out that, today values education is tried to be given inside various other classes' context. Cihan comments on this situation as "an occurring need for a developed, non-random, planned and efficient values education."

- Teacher candidates complain about the lack of application in the values education. Internship applications should be enriched with quality and structure in which values education should also take place in the process. 


\section{International Journal of Science and Research (IJSR) \\ ISSN (Online): 2319-7064}

Index Copernicus Value (2016): 79.57 | Impact Factor (2015): 6.391

\section{References}

[1] Aladağ, S. (2012). İlköğretim Sosyal Bilgiler Öğretiminde Değer Eğitimi Yaklaşımlarının Öğrencilerin Sorumluluk Değerini Bilişsel Düzeyde Kazanmalarına Etkisi. Türkiye Sosyal Araştırmalar Dergisi, 16(1), 123-146.

[2] Altunay, E. ve Yalçınkaya, M. (2011). Öğretmen adaylarının bilgi toplumunda değerlere ilişkin görüşlerinin bazı değişkenler açısından incelenmesi. Kuram ve Uygulamada Eğitim Yönetimi, 17 (1), 5-28.

[3] Bacanlı, H. (1999). Duyuşsal Davranış Eğitimi. Ankara: Nobel Yayın Dağııım.

[4] BALCI, A. (2013). Sosyal Bilimlerde Araştırma Yöntem, Teknik ve İlkeler (10. Baskı). Ankara: Pegem Akademi.

[5] Balcı, N. (2008). İlköğretim 6. Sınıf Sosyal Bilgiler Dersinde Değer Eğitiminin Etkililiği (Yayınlanmamış yüksek lisans tezi). Marmara Üniversitesi, İstanbul.

[6] Cihan, N. (2014). Okullarda Değerler Eğitimi ve Türkiye'deki Uygulamaya Bir Bakış. Turkish Studies, 9 (2), 429-436.

[7] Dönmez, C. (2006). Değerler Eğitiminde Kahramanların Kullanımına Bir Örnek: Mustafa Kemal Atatürk, Gazi Eğitim Fakültesi Dergisi, 26 (2), 113133.

[8] Halstead, J. M. \& Taylor, M. J. (2000). Learning and teaching about values: a review of recent research. Cambridge Journal of Education. 30 (2), 169-202.

[9] Öncül, R. (2000). Eğitim ve Eğitim Bilimleri Sözlüğü. İstanbul: Milli Eğitim Basımevi.

[10] Özgüven, İ. E. (1999). Psikolojik Testler. Ankara: Pdrem Yayınları.

[11] Schwartz M. J. (2008). Teacher Education for Moral and Character Education. In L. P. Nucci and D. Narvaez (Eds.), Handbook of Moral and Character Education. New York and London: Routledge.

[12] Sharma, S. R. (2003). Encyclopaedia of Value and Moral Education. New Delhi: Cosmo Publications.

[13] Simon S. B., Howe L. W. and Kirschenbaum H. (1972). Values Clarification; A Handbook Of Practical Strategies For Teachers and Students. New York: Hart Pub. Co.

[14] Suvirananda, S. (2005). Value Education in Secondary Schools: Methodology. Journal of Value Education. January \& July 2005.

[15] Şahin, T. (2013). Sosyal bilgiler öğretmen adaylarının değerler eğitimi öz-yeterliliklerinin incelenmesi. Yayınlanmamış Yüksek Lisans tezi, Marmara Üniversitesi Eğitim Bilimleri Enstitüsü, İstanbul.

[16] Üstünyer, F. (2009). Karakter Ĕgitimi ile İlgili Eğitici Görüşleri. Yayınlanmamış Yüksek Lisans Tezi. Yeditepe Üniversitesi. İstanbul.

[17] Venkataiah, N. (2007). Value Education. New Delhi: APH Publishing Corporation.

[18] Yazıcı, K. (2006). Değerler Eğitimi'ne Genel Bir Bakış. Türklük Bilimi Araştırmaları, 19, 499-522. 